\title{
THE TRUTH ABOUT FLAT-RATE INCOME TAX IN ROMANIA
}

\author{
Claudiu DOLTU1
}

DOI: 10.35782/JCPP.2019.1.01

\begin{abstract}
This article is about the Myth' of the flat rate income tax in Romania. It is not meant to add another argument for the 'pros' or for the 'cons' (the flat rate income tax or progressive income tax debate). It is simply a reality check of the Income Tax system Romania adopted in early 2006, which started and maintained not only many academic, but also even stronger public policy debates ever since. This article shows that accepting a necessary basic distinction between the nominal and the effective tax rate ends any 'debate' on the subject. Why? Because Romania never had and still does not apply a flat rate income tax, but a progressive income tax rate. The study uses data from 2012 and 2018 and shows how eight effective tax rates and not a single income tax rate were applied in 2012 and five effective income tax rates exist today. ${ }^{2}$ These evidences were always available not just for the experts and public policy decision makers, but also for the public. They were and still are simply ignored on the background of a misleading ideological noise.
\end{abstract}

Keywords: fiscal policy, income tax, progressive taxation, nominal tax rate, effective tax rate, tax burden, government budget, redistribution, efficiency, equity.

\section{Background: Creating a false problem}

Since the marginal income tax rate has been reduced to 16 percent and the same 16 pecent was applyed to the profit tax (early 2006), strong critiqe never ended against a so-called fully fledged income tax rate in Romania. The main contesting argument is rather ideological than economic. The relatively low income tax rate was and is still considered unappropriate, injust and quite imoral as taxation is viewed merely as an instrument of social justice. This is the ideological origin of the contesting. Nothing wrong with it as long as it would be transparentely assumed. Unfortunately, this is not the case. The critique is presented from the perspective of the relatively low level of the government revenue stated as percent of the GDP. Historically, Romania's government

1 Professor, The Bucharest University of Economic Studies. E-mail: claudiu.doltu@gmail.com

2 Some changes of the tax system were adopted in 2018, when the wage and profit tax rate were reduced from 16 percent to 10 percent. These changes also affected the social contributions (unemployment, pension, etc.), health contributions as well as the brackets for basic deductions. 
revenues didn't exceed 30 percent of the GDP, significantly lower compared with the EU average (40 percent). ${ }^{1}$

In essence, this view favours the higher level of taxation to ensure additional government revenues and the progressive taxation to enhance social justice. The main argument for higher tax rates is the government's need for additional resources in order to provide more goods to its citizens (education, health, pensions, social protection, physical infrastructure - public roads, highways, railwails, airports -, public order, judicial system, national defence etc.)

The relatively low level of government revenues stated as percentage of the GDP compared with other EU countries is often used as the main excuse for the relatively low quality of the services the public sector offers to citizens. The envisaged solution would be higher taxes, mainly income taxes (profit, wage etc.), bundeled with progressive taxation. Thus, more government revenue would be secured and social justice would be enhanced.

\section{Reality check: There is no flat rate income tax in Romania}

When it comes to taxation, is easy to create a false problem. Taxation is everywhere and always a sensitive issue. The tax system, especially when wages are brought into discussion, generates many emotions. However, besides, passion, it is easy to understand that, in Romania, there was not a single income tax rate after 2006 and that is not the case today. Why? Simply because we indeed apply a single tax rate (16 percent before 2018, and 10 percent after the changes adopted in 2018) to different tax bases.

\section{Box 1. How the income tax is calculated in Romania}

From the gross wage the unemployment contribution and the so-called social contributions (pension, and other social contributions) are retained. Then, (only) for some wages - not exceeding a certain level - a „basic deduction”is applied/subtracted (for wages exceeding a certain level the basic deduction does not apply). What remains is called „The Tax Base”. On this base the 16 percent or 10 percent tax rate is levied (16 percent between 2006-2017 and 10 percent since 2018 onward) ${ }^{2}$.

${ }^{1}$ France, Belgium, Denmark apply the highest tax rates among the other EU countries with total tax revenues above 45 percent of the GDP. Sweden, Finland, Austria, Italy, Greece and Germany are following, with government tax revenue between 40 and 45 percent of GDP. Luxembourg, The Netherlands, Hungary, Croatia, Portugal, Slovenia, UK, Czehia and Poland follow with government tax income between 40 and 35 percent of the GDP. Spain, Cyprus, Estonia, Malta, and Slovakia come after this group with government revenue between 35 and 30 percent of the GDP. Latvia, Lithuania, Bulgaria, Romania and Ireland are at the bottom level of taxation with government tax revenue slightly above 30 percent of GDP (Latvia and Lithuania) and below 30 percent of GDP - Romania, Bulgaria and Ireland. (Eurostat, 2018)

2 Between 2006-2017, the Unemployment contribution and the Social Contributions represented 11 percent of the gross wage - contributions to the pension was equally shared by the employer and the employee (each covering 10.5 percent of the gross wage) and the Health contribution 


\section{A simple game with 16 percent income tax rate (2006-2017)}

The Romanian fiscal authorities brake down the gross wage in several (size) categories. Randomly, we consider three individuals with three different gross wages from three different categories (as considered by the fiscal authorities when forecasting the budget revenues). The first individual has a monthly gross wage of RON 1,277. For the second and the third individual, the monthly gross wage is RON 2,808 and RON 6,968 respectively.

The common perception (and the wrong one) is that all these three individuals have to pay to the government the same 16 percent Wage Tax. In fact, they bear three different effective wage tax rates: 12 percent the first individual, 15 percent the second one and 16 percent the third one. Why?

\section{Calculating the effective tax rate for the first individual, the one getting the lowest gross wage:}

The Gross Wage (RON 1,277) - Unemployment and Social Contributions (RON 140) - Health Contribution $($ RON 70) $=$ The Wage Revenue. Then, subtracting the "Basic Deduction" (RON 260) gets the tax base (RON 807).

Applying 16 percent (the nominal wage tax rate) to this tax base gets the amount this person pays to the government: RON 129 (16 percent of RON 807). This is only 12 percent of the Wage Revenue - as defined by the Romanian fiscal authories. Thus, 12 percent is the Effective Wage Tax Rate for the first individual and not 16 percent as most people used to see.

\section{Calculating the effective tax rate for the second individual:}

The same calculations for the second individual lead to a different tax base. The gross wage (RON 2,808) - unemployment and social contributions (RON 309) - Health contribution (RON 154) gives a Wage Revenue of RON 2,345. From this amount, a base deduction in amount of RON 150 is subtracted, which gives the tax base (RON 2,195). The wage tax paid to the government is, in this case, RON 351 (16 percent of RON 2,195). The amount paid to the government as wage tax (RON 351) is only 15 percent of the wage revenue. 15 percent is the Effective Wage Tax Rate for the second individual and not 16 percent as most people used to see.

\section{Calculating the effective tax rate for the third individual, the one getting the highest gross wage:}

The same definitions and steps/subtractions, applied now for the third individual, with a notable distinction from the previous two gross wages: no basic deduction is applicable. RON 6,968 is considered a high wage and no basic deduction is applied for (gross) wages that exceed a certain level. For this high wage only, the amount paid to

paid by the employee represented 5.5 percent of the gross wage. The nominal wage tax rate was 16 percent. These rates changed starting 2018. Unemployment, pension and other social contributions increased to $25 \%$ of the gross wage (as the full pension contribution was transferred to the employee), and the nominal wage tax rate was reduced to 10 percent. 
the government represents 16 percent of the Wage Revenue. 16 percent is the Effective Wage Tax Rate - as for all wages considered high and for which any basic deduction is not applicable.

Few simple evidence: firstly, three individuals from three different brackets of gross wages (brackets are defined by fiscal authorities) pay different amounts to the government. Not only their unemployment contributions and other social contributions are different, but also the effective wage tax rates. Secondly, the higher the wages are, the more the amounts paid to the government as taxes increase (also, when the gross wage exceeds a certain level any basic deduction cease to apply).

The second individual, getting a gross wage of RON 2,808, pays to the government more than the first one who gets a gross wage of just RON 1,277, and the third individual (with a gross wage of RON 6,968) pays more to the government against the second (rich) one.

\section{Table 1. Contributions and taxes to state for three different brackets of gross wages}

\begin{tabular}{|l|c|c|c|}
\cline { 2 - 4 } \multicolumn{1}{c|}{} & $\begin{array}{c}\text { First } \\
\text { individual } \\
\text { (gross wage } \\
\text { RON 1,277) }\end{array}$ & $\begin{array}{c}\text { Second individual } \\
\text { (gross wage } \\
\text { RON 2,808) }\end{array}$ & $\begin{array}{c}\text { Third individual } \\
\text { (gross wage } \\
\text { RON 6,968) }\end{array}$ \\
\hline Unempl. and Social Contrib. & 140 & 309 & 766 \\
\hline Health Contribution & 70 & 154 & 383 \\
\hline Wage Revenue Tax & 129 & 351 & 931 \\
\hline Total paid to the government & 339 & 814 & 2080 \\
\hline
\end{tabular}

In other words, the progressive income tax system was well and alive in Romania after 2006, when the 16 percent tax rate was introduced for the most categories of revenues (most relevant and sensitive being wages and profits). It is still in place today.

\section{Nominal vs. Effective Income Tax Rate}

People are often misguided by the nominal values of economic data. The rational individuals use real values rather than nominal when evaluating the costs and benefits of their decisions. It is easy to distinguish between real and nominal economic data/variables, such as nominal vs. real interest rates, nominal vs. real GDP. Many people consider these differences. The same is true with the gross wage/income vs. net wage/income. However, it is not the same when it comes to the distinction between the nominal income tax rate and effective income tax rate.

The Effective Income Tax Rate is the ratio between the wage tax paid by the employee and the wage revenue times one hundred. The wage revenue is what remains after the unemployment contribution, social contributions and the health contributions are subtracted from the gross wage. A basic deduction is applied to this wage revenue (for 
wages not exceeding a legally defined level). The result is the tax base on which the nominal tax rate (16 percent before 2018 and 10 percent afterwards) is applied.

However, not many people know how their wage tax is calculated. They may pay some attention to their gross wage and to their net monthly wage in absolute amounts (e.g., they may check the balance of their bank accounts to see if they were paid on certain days of the months or many of them are paid in cash). But the details - how much they pay for the future pension or for the social contributions, health, or is any basic deduction applicable for them or where their contributions go? etc. - are most often ignored. Most employees in Romania have a single job. Their wage tax is retained at the source of payment (retained by the employer and paid/transferred to the fiscal authorities). As many do not have other revenue sources (recognized and legally declared), why should they have any concerns on accounting or fiscal details? These characteristics explain, to a large extent, why it is so easy to ignore the difference between the nominal wage tax rate and the effective wage tax rate.

Table 2. Eight Effective Income Tax Rates in 2012

\begin{tabular}{|c|c|c|c|c|c|}
\hline $\begin{array}{c}\text { Gross wage } \\
(\mathbf{R O N})\end{array}$ & $\begin{array}{c}\text { Social } \\
\text { insurances* } \\
\text { (RON) }\end{array}$ & $\begin{array}{c}\text { Wage } \\
\text { Income } \\
\text { (RON) }\end{array}$ & $\begin{array}{c}\text { Deduction } \\
\text { (RON) }\end{array}$ & $\begin{array}{c}\text { Wage } \\
\text { Tax } \\
\text { (RON) }\end{array}$ & $\begin{array}{c}\text { Effective/real } \\
\text { income tax rate } \\
\text { (\%) }\end{array}$ \\
\hline 658 & 109 & 549 & 280 & 43 & 8 \\
\hline 700 & 116 & 585 & 280 & 49 & 8 \\
\hline 800 & 132 & 668 & 280 & 62 & 9 \\
\hline 928 & 153 & 775 & 280 & 79 & 10 \\
\hline 1,277 & 211 & 1,066 & 260 & 129 & 12 \\
\hline 1,599 & 264 & 1,335 & 240 & 175 & 13 \\
\hline 1,707 & 282 & 1,426 & 230 & 191 & 13 \\
\hline 1,884 & 311 & 1,573 & 220 & 216 & 14 \\
\hline 2,808 & 463 & 2,345 & 150 & 351 & 15 \\
\hline 4,009 & 661 & 3,347 & 0 & 536 & 16 \\
\hline 5,233 & 864 & 4,370 & 0 & 699 & 16 \\
\hline 5,967 & 984 & 4,982 & 0 & 797 & 16 \\
\hline 6,968 & 1,150 & 5,818 & 0 & 931 & 16 \\
\hline 8,205 & 1,354 & 6,851 & 0 & 1,096 & 16 \\
\hline 15,700 & 2,591 & 13,110 & 0 & 2,098 & 16 \\
\hline
\end{tabular}

Source: Own calculations based on Ministry of Public Finance's data.

* Unemployment, social contributions (pension, etc.) and health contribution.

In 2012, the Ministry of Public Finance used 14 intervals of revenues to forecast the budget revenues (see Table 1). Using these intervals to calculate the effective wage tax rate is easy to understand that when a single nominal tax rate was levied on the wages, in fact, eight effective wage tax rates existed (Doltu, 2012). The progressive taxation was there, alive and well. 
Table 3. Five Effective Income Tax Rates in 2018

\begin{tabular}{|c|c|c|c|c|c|}
\hline $\begin{array}{c}\text { Gross wage } \\
\text { (RON) }\end{array}$ & $\begin{array}{c}\text { Social } \\
\text { insurances* } \\
\text { (RON) }\end{array}$ & $\begin{array}{c}\text { Wage } \\
\text { Income } \\
\text { (RON) }\end{array}$ & $\begin{array}{c}\text { Deduction } \\
\text { (RON) }\end{array}$ & $\begin{array}{c}\text { Wage } \\
\text { Tax } \\
\text { (RON) }\end{array}$ & $\begin{array}{c}\text { Effective/real } \\
\text { income tax rate } \\
\text { (\%) }\end{array}$ \\
\hline 1,574 & 551 & 1,023 & 470 & 55 & 5 \\
\hline 1,863 & 652 & 1,211 & 470 & 74 & 6 \\
\hline 2,085 & 730 & 1,356 & 437 & 92 & 7 \\
\hline 2,665 & 933 & 1,732 & 298 & 143 & 8 \\
\hline 3,863 & 1,352 & 2,511 & 0 & 251 & 10 \\
\hline 5,408 & 1,893 & 3,515 & 0 & 351 & 10 \\
\hline 6,952 & 2,433 & 4,519 & 0 & 452 & 10 \\
\hline 8,497 & 2,974 & 5,523 & 0 & 552 & 10 \\
\hline 10,042 & 3,515 & 6,527 & 0 & 653 & 10 \\
\hline 11,587 & 4,055 & 7,531 & 0 & 753 & 10 \\
\hline 13,132 & 4,596 & 8,536 & 0 & 854 & 10 \\
\hline 14,676 & 5,137 & 9,540 & 0 & 954 & 10 \\
\hline 16,993 & 5,948 & 11,045 & 0 & 1,105 & 10 \\
\hline 26,400 & 9,240 & 17,160 & 0 & 1,716 & 10 \\
\hline
\end{tabular}

Source: Own calculations based on Ministry of Public Finance's data.

* Unemployment, social contributions (pension, etc.) and health contribution.

In 2018, the Ministry of Public Finance used 13 intervals of revenues to forecast the budget revenues (see Table 2). Using these intervals to calculate the effective wage tax rate, it is obvious that when a single nominal tax rate was levied on the wages $(10$ percent) in fact five effective wage tax rates existed. The progressive taxation was still alive and de facto used.

\section{Conclusions}

As a progressive wage tax rate is de facto applied in Romania, the debate on progressive vs. flat rate income taxation leads to a dead end. No government would succeed to generate more resources and better serve its citizens simply by changing the fiscal legislation and changing the "Mathematics" of the tax calculations. While the increase of the government revenues could be a reasonable objective of the fiscal policy, more attention should be devoted to the pragmatic elements of the fiscal system and to its economic features.

The progressive character of taxation is by far less important than the understanding of the income tax elasticity. Historically, Romania's tax collecting system is less efficient compared with other EU countries not because a single tax rate is levied on wages (and profits). While it is true that the "rich countries" tax more than "poorer" countries, this does not mean that in order to increase the well-being of a country, the taxation must 
be first increased ${ }^{1}$. For sure, this means that to be able to tax more, a government must first make sure that the economy grows first.

There is no such thing as a "Golden Rule" in fiscal policy (one size fits all, or what works well in a country will perform absolutely great in another country). However, some pragmatic features can be identified and used when it comes to increasing government tax revenues.

Good practices around the world show that the efficiency of a tax system can be increased without discouraging the risk taking necessary to develop economic activities. The existing financial structure and the relevance of the large taxpayers are among them. Also, if the incentive structure is not a good one, the informal economy would continue to remain at high levels and the government revenue could not significantly increase.

Easy prediction and the stability of the fiscal legislation are major factors to reduce the uncertainty. A "Large tax base and lower tax rates" approach proved to reduce the incentives for tax evading.

Fiscal incentives in the form of various privileges - mainly when arbitrary selecting winners and losers for the future economic activities - proved to be not just costly for the budget, but also a sure way to encourage corruption and rent seeking.

Enhancing the administrative capacity of the fiscal authorities could also increase the efficiency of the tax collection system without necessary operating major changes in fiscal legislation (World Bank, 2012) Before operating any changes in the architecture of the fiscal system and its administrative infrastructure, a political economy mapping could be a very useful instrument in order to identify the necessary allies and opponents to any envisaged changes (Doltu, 2018). Considering the existing conditions of Romania, the 'justice approach' in fiscal policy could very well co-exist with a 'pragmatic approach'.

\section{References}

Doltu, C. (2012). The Rational Fiscal Policy, Ziarul Financiar, 7.11. 2012

Doltu, C. (2018). Political economy map- A useful tool for public policy decision makers. Theoretical \& Applied Economics, 25(1), 5-14.

Eurostat (2018). Statistics Explained

The World Bank (2012). Romania Public Finance Functional Review

1 At the beginning of the 2000 years, the average levels of taxation in developed countries (35 percent of GDP) were two times higher than in developing countries (17 percent). 